WIDER Working Paper 2017/54

Institutional arrangements for biofuel feedstock production in Zambia

Paul C. Samboko and Cliff Dlamini*

March 2017 
Abstract: Given likely increases in biofuel demand across Southern Africa, we identify suitable production models in Zambia for the Southern African market. This is crucial given, on the one hand, the problems of contract failure and transaction costs that plague outgrower models in Southern Africa and, on the other, the uniqueness of crops with respect to input requirements and characteristics. In this paper, we review existing cash crop production models that can be used for biofuel feedstock production in Zambia with a special focus on sugarcane and seed cotton. We find the organization of the Kaleya, Manyonyo, and Magobbo irrigation schemes as candidate institutional arrangements for bioethanol feedstock production. For biodiesel feedstocks, the Dunavant (NWK Agri-services) distributor model is best suited to increased smallholder participation.

Keywords: biofuels, feedstocks, institutional arrangements Zambia, Southern Africa JEL classification: L23, O13, N77, O19, Q16

* Both authors: Indaba Agricultural Policy Research Institute (IAPRI), Lusaka, Zambia; corresponding author: sambokopc@gmail.com

This study has been prepared within the UNU-WIDER project on 'Regional growth and development in Southern Africa'.

Copyright (C) UNU-WIDER 2017

Information and requests: publications@wider.unu.edu

ISSN 1798-7237 ISBN 978-92-9256-278-6

Typescript prepared by Joseph Laredo.

The United Nations University World Institute for Development Economics Research provides economic analysis and policy advice with the aim of promoting sustainable and equitable development. The Institute began operations in 1985 in Helsinki, Finland, as the first research and training centre of the United Nations University. Today it is a unique blend of think tank, research institute, and UN agency_providing a range of services from policy advice to governments as well as freely available original research.

UNU-WIDER acknowledges specific programme contribution from the National Treasury of South Africa to its project 'Regional growth and development in Southern Africa' and core financial support to its work programme from the governments of Denmark, Finland, Sweden, and the United Kingdom.

Katajanokanlaituri 6 B, 00160 Helsinki, Finland

The views expressed in this paper are those of the author(s), and do not necessarily reflect the views of the Institute or the United Nations University, nor the programme/project donors. 
The commercial production of liquid biofuels (i.e. bioethanol and biodiesel) in Africa is expected to increase in the near future following pronouncements that mandatory blending mandates are to be introduced in South Africa, and renewed interest in Zambia (Wenberg 2013; Stone et al. 2015). Although commercial production is yet to materialize in most Southern African countries, understanding what a viable industry will require remains crucial. Previously, commercial production failed in a number of countries for a number of reasons, including poor understanding of the local environment, lack of feedstock, and previous experiences with biofuels (Schoneveld et al. 2011; German et al. 2011; MEWD 2016). To set up a viable industry, it is crucial that the building blocks are in place. These include:

- Sustained production of cost-effective feedstocks

- Demonstrable benefits for firms, farmers, and the economy at large

- An understanding of the biophysical and social limitations of industry expansion

- Supportive incentives, regulation, and government policies

- Adequate demand for liquid biofuels.

For Zambia, on the basis of current production levels, bioethanol production is likely to use sugarcane, cassava, sweet sorghum, and soya bean, while groundnuts and sunflower are identified as potential biodiesel feedstocks (Samboko et al. forthcoming a). We hypothesize that both South Africa's and Zambia's demand for bioethanol can be met using two or more large-scale investments - with feedstock land requirements estimated at 200,000 hectares (ha). However, the production model adopted is likely to have an impact on smallholder participation and the resulting spillovers to the rural population: large investments may exclude smallholders from accessing high-value commodity markets, while smaller ones may allow widespread participation (Sartorious et al. 2003), and there is scope for non-farm income gains by migratory labour working on these large-scale farms.

However, there is a need to understand what production models are best suited to feedstock production given past failures in biodiesel feedstock production. Previous attempts have limited the analysis of institutional arrangements to one sugarcane outgrower scheme; the organization of other schemes or models has not been analysed (see, for example, Shumba et al. 2011). Furthermore, previous experience with biofuels in Africa has generated little or no evidence relating to the performance of feedstock production models. Failure to produce feedstocks was linked more to the poor performance of jatropha as a feedstock of choice under local conditions than the institutional arrangements for production (German et al. 2011; MEWD 2016). However, there are some indications of dissatisfaction among farmers with contracts (for example, lengthy contracts were often not signed by firms) and inadequate agricultural extension service provision (Loos 2009; CSBF 2010). This underscores the importance of having proper institutional arrangements that will guarantee sustained feedstock production.

Given the differences in feedstock characteristics (and their input requirements) for bioethanol and biodiesel, and the need for uniform-quality feedstocks, production models for optimal production will differ. For example, bioethanol feedstocks such as sugarcane and sweet sorghum will yield more ethanol per unit if transported to the mill shortly after harvesting, while for biodiesel, this is not critical, as the feedstock's oil content will not decline sharply with delayed processing. The choice of feedstock production model will also differ according to the scale of biofuel production (i.e. small or large). Moreover, an appropriate model will be dependent on 
what works under local conditions, and will be one that does not yield negative social outcomes to a degree that the costs from bioenergy investments far outweigh the benefits. From the bioenergy firm's perspective, an appropriate model is crucial given the problems with outgrowers, namely transaction costs and the enforcement of contracts (Sartorious et al. 2003).

The primary objective of this paper is to identify suitable institutional arrangements for biofuel feedstock production in Zambia. This is done through a review of the literature on institutional arrangements for producing sugarcane and seed cotton.

\section{Institutional arrangements for biofuel feedstock production in Zambia}

\subsection{A review of biofuel feedstock production models}

The literature on biofuel production models identifies four main typologies depending on the intended use and scale of feedstock production (Table 1). Where type 1 and 2 models are mainly for small-scale biofuel production, usually for local consumption, type 3 and 4 models involve production on a large scale to meet both local and international demand-and these are the most prevalent models (Gasparatos 2012). The difference between types 3 and 4 is that type 3 involves outgrowers under either a centralized outgrower model or a nucleus estate, while type 4 involves farmers under large-scale commercial plantations. Farmers under type 3 cultivate up to 99 ha of land, while those under type 4 cultivate 100 ha or more. Previously, firms in Zambia adopted the type 3 production model, but most of these have exited the industry or ventured into other businesses. There is no record of the performance of feedstock production models in Zambia, even though there is plenty of information regarding the failure of projects, which, as mentioned above, is mostly attributed to a poor understanding and performance of jatropha under local conditions.

Table 1: Types of biofuel production model

\begin{tabular}{|c|c|c|}
\hline \multirow[b]{2}{*}{ Target market } & $\begin{array}{l}\text { Smallholder farmers cultivating up } \\
\text { to } 99 \text { ha }\end{array}$ & $\begin{array}{l}\text { Large-scale farmers cultivating } \\
\text { over } 100 \text { ha }\end{array}$ \\
\hline & Scale of project & \\
\hline $\begin{array}{l}\text { Local users at the national or sub- } \\
\text { national levels }\end{array}$ & $\begin{array}{l}\text { Type 1: e.g. Projects in Zambia } \\
\text { such as Thomro Biofuels, Southern } \\
\text { Biopower, Macha works, Africa } \\
\text { works, and Stichting Nederlandse } \\
\text { Vrijwilligers (SNV) }\end{array}$ & $\begin{array}{l}\text { Type 2: Mines such as Kansanshi, } \\
\text { and commercial farms in central } \\
\text { Zambia }\end{array}$ \\
\hline $\begin{array}{l}\text { Local or international users to meet } \\
\text { blending mandates }\end{array}$ & $\begin{array}{l}\text { Type 3: Mainly outgrowers and } \\
\text { smallholder farmers linked to } \\
\text { biofuel processing companies, e.g. } \\
\text { abandoned projects such as Marli } \\
\text { investments and D1 oils }\end{array}$ & $\begin{array}{l}\text { Type 4: Commercial plantations } \\
\text { such as those used for timber and } \\
\text { paper production, producing mainly } \\
\text { for the European Union market }\end{array}$ \\
\hline
\end{tabular}

Source: Adapted from von Maltitz (2009).

The identification of an appropriate feedstock production model for Zambia relies not only on an understanding of the drivers of success and failure among existing cash crop production models, but also on the nature of the feedstock to be used. For bioethanol, given that the sugar content of feedstock decreases with time from harvest for crops like sugarcane, cassava, and sweet sorghum, which are the likely feedstocks of choice for Zambia (Samboko et al. forthcoming a), production will certainly have to follow a centralized or nucleus estate production arrangement, in which the processing facility is located near the feedstock production zone(s), as is the case for sugar production in various irrigation schemes in Mazabuka district. In 
contrast, for biodiesel, it is possible to locate processing plants far from the points of feedstock production without any losses in oil content.

The implication of this is that for biodiesel feedstocks, any of the production models in Table 1 can be used, while for bioethanol feedstocks, the type 3 and 4 models are the most appropriate, with limited smallholder engagement near the processing plant(s). However, even if feedstock production for biodiesel can use any of the four models, for investments with high asset specificity, the use of types 1 and 2 is likely to pose high risks with regard to the need for sustained feedstock supply in sufficient quantities.

For production of feedstocks under the nucleus estate type model, suitable candidates are the one used by Kaleya Smallholder Company Limited in Mazabuka district, Southern province, and variants used in the Magobbo and Manyonyo irrigation schemes, also in Southern province. The model traces its origin from the Commonwealth Development Corporation, which proposed it in most Southern African countries in the 1980s (Mungandi et al. 2012). We review these and their characteristics in Section 2.2. For biofuel production at small- to medium-scale levels, Dunavant's (now NWK) distributor-outgrower model has been shown to be successful in Zambia for cotton production. Characteristics of the outgrower models used in Zambia are summarized in Table 2.

Table 2: Outgrower models in Zambia

\begin{tabular}{|c|c|c|c|c|}
\hline & & \multicolumn{3}{|l|}{ Model } \\
\hline \multirow{5}{*}{ 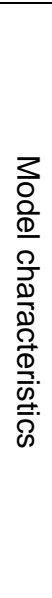 } & & Centralized & Distributor & Intermediary \\
\hline & Extension service & $\begin{array}{l}\text { Own extension/depot } \\
\text { staff }\end{array}$ & Local agents (distributors) & $\begin{array}{l}\text { Semi-commercial } \\
\text { farmers of } \\
\text { intermediary } \\
\text { organizations }\end{array}$ \\
\hline & $\begin{array}{l}\text { Number of } \\
\text { smallholders } \\
\text { involved }\end{array}$ & Intermediate & Large & Limited \\
\hline & $\begin{array}{l}\text { Geographical } \\
\text { concentration }\end{array}$ & $\begin{array}{l}\text { Few areas with high } \\
\text { potential }\end{array}$ & $\begin{array}{l}\text { Widespread production over } \\
\text { large parts of the country }\end{array}$ & $\begin{array}{l}\text { Close to central } \\
\text { processing plant }\end{array}$ \\
\hline & Credit recovery rate & $\begin{array}{l}\text { Problematic when many } \\
\text { companies deal in the } \\
\text { same commodity }\end{array}$ & $\begin{array}{l}\text { Can be problematic if there } \\
\text { are several companies } \\
\text { dealing in the same } \\
\text { commodity }\end{array}$ & Often not problematic \\
\hline
\end{tabular}

Source: World Bank (2007).

\subsection{Large-scale production models for bioethanol feedstocks}

Considering that large-scale feedstock production is likely to take place in 7 of the 10 farming blocks being established by the Zambian government across the 10 provinces, there have been a number of irrigation-based models that are candidate institutional models for biofuel production, including the Kaleya Smallholder Company Limited (KASCOL), Manyonyo, and Magobbo irrigation schemes. The models have significant similarities with respect to institutional arrangements, but there are clearly observable differences. We discuss the characteristics of the three models below (Table 3). 
Table 3: Sugarcane irrigation schemes and their characteristics

\begin{tabular}{|c|c|c|c|}
\hline & \multicolumn{3}{|l|}{ Irrigation scheme } \\
\hline & KASCOL & Magobbo & Manyonyo \\
\hline $\begin{array}{l}\text { Management } \\
\text { model }\end{array}$ & $\begin{array}{l}\text { Large sugar cane estate with } \\
\text { commercial and smallholder } \\
\text { plots. Land owned by GRZ. } \\
\text { Smallholders formally } \\
\text { responsible for their own plot, } \\
\text { but have to exactly follow } \\
\text { instructions from overall estate } \\
\text { management. }\end{array}$ & $\begin{array}{l}\text { Farmer-owned sugarcane } \\
\text { scheme of around } 400 \text { ha. } \\
\text { Farmers have block title. } \\
\text { Management of scheme fully } \\
\text { outsourced to a Zambia } \\
\text { Sugar subsidiary. }\end{array}$ & $\begin{array}{l}\text { Managed by farmer-owned } \\
\text { company with professional } \\
\text { staff. }\end{array}$ \\
\hline Ownership level & $\begin{array}{l}\text { Very low - smallholders do not } \\
\text { own the land and are minority } \\
\text { shareholders in the estate. } \\
\text { They cannot decide what to do } \\
\text { on their plot. }\end{array}$ & $\begin{array}{l}\text { Theoretically high because } \\
\text { of block title, but farmers } \\
\text { have little practical influence } \\
\text { on management. }\end{array}$ & $\begin{array}{l}\text { Medium-100\% owners of } \\
\text { the company-but Board } \\
\text { has many other members } \\
\text { and Zambia Sugar tends to } \\
\text { try to control all smallholder } \\
\text { outgrowers. }\end{array}$ \\
\hline $\begin{array}{l}\text { Criteria for } \\
\text { participation }\end{array}$ & $\begin{array}{l}\text { No procedure laid down for the } \\
\text { initial selection, which was } \\
\text { carried out by chiefs and } \\
\text { politicians. }\end{array}$ & $\begin{array}{l}\text { No criteria; farmers in project } \\
\text { area were selected for } \\
\text { participation. }\end{array}$ & $\begin{array}{l}\text { No formal procedure; } \\
\text { existing farmers were } \\
\text { selected for participation by } \\
\text { default. Areas for } \\
\text { development were chosen } \\
\text { based on vulnerability } \\
\text { following construction of } \\
\text { the Kariba dam. }\end{array}$ \\
\hline $\begin{array}{l}\text { Main production } \\
\text { decision-maker }\end{array}$ & KASCOL & $\begin{array}{l}\text { Zambia Sugar through its } \\
\text { subsidiary }\end{array}$ & $\begin{array}{l}\text { Manyonyo Irrigation } \\
\text { Company }\end{array}$ \\
\hline $\begin{array}{l}\text { Authority } \\
\text { charged with } \\
\text { initial production } \\
\text { management }\end{array}$ & $\begin{array}{l}\text { KASCOL for } 3 \text { years while } \\
\text { farmers built capacity }\end{array}$ & Zambia Sugar subsidiary & $\begin{array}{l}\text { African Management } \\
\text { Services Company for } 1 \\
\text { year with negotiations for } \\
\text { extension }\end{array}$ \\
\hline Land ownership & $\begin{array}{l}\text { Land is owned by GRZ, leased } \\
\text { to KASCOL for } 99 \text { years. } \\
\text { Individual farmers are } \\
\text { allocated } 6-7.5 \text { ha of land on a } \\
\text { 14-year sub-lease. }\end{array}$ & $\begin{array}{l}\text { Initially owned by individuals } \\
\text { under leasehold and } \\
\text { customary tenure. It is now } \\
\text { under block title, owned by } \\
\text { the company. }\end{array}$ & $\begin{array}{l}\text { Land is owned by private } \\
\text { individuals, and some of it } \\
\text { under customary tenure-- } \\
\text { titled with offer letters in } \\
\text { some cases. }\end{array}$ \\
\hline $\begin{array}{l}\text { How initial } \\
\text { infrastructure } \\
\text { was provided }\end{array}$ & $\begin{array}{l}\text { Funding from DBZ, GRZ, and } \\
\text { Zambia Sugar }\end{array}$ & $\begin{array}{l}\text { The European Union funded } \\
60 \% \text { of the project costs } \\
\text { through the Ministry of } \\
\text { Agriculture; the rest was } \\
\text { funded by project } \\
\text { beneficiaries. }\end{array}$ & $\begin{array}{l}\text { Funding from the African } \\
\text { Development Bank, GRZ, } \\
\text { and the Ministry of Foreign } \\
\text { Affairs (MFA) Finland. } \\
\text { Infrastructure provided by } \\
\text { the Ministry of Agriculture. }\end{array}$ \\
\hline $\begin{array}{l}\text { Authority } \\
\text { providing inputs } \\
\text { for production }\end{array}$ & $\begin{array}{l}\text { Kaleya Smallholder Company } \\
\text { Limited }\end{array}$ & $\begin{array}{l}\text { Zambia Sugar plc through its } \\
\text { subsidiary }\end{array}$ & $\begin{array}{l}\text { Manyonyo Irrigation } \\
\text { Company, which is farmer- } \\
\text { owned }\end{array}$ \\
\hline $\begin{array}{l}\text { Degree of farmer } \\
\text { participation in } \\
\text { production } \\
\text { activities }\end{array}$ & $\begin{array}{l}\text { High-farmers do most of the } \\
\text { crop management themselves } \\
\text { on their own plot, including } \\
\text { irrigation. }\end{array}$ & $\begin{array}{l}\text { Very low-some work as } \\
\text { labourers in the scheme; } \\
\text { some are not involved at all. }\end{array}$ & $\begin{array}{l}\text { Low (optionally as } \\
\text { labourers)-the scheme is } \\
\text { managed by the company. }\end{array}$ \\
\hline $\begin{array}{l}\text { Profitability per } \\
\text { ha }\end{array}$ & $€ 1,200$ & $€ 1,500$ & $€ 1,050$ \\
\hline $\begin{array}{l}\text { Net income to } \\
\text { farmers }\end{array}$ & Data unavailable & ZMW5,000 per month & ZMW12,000 per month \\
\hline Funding & $\begin{array}{l}\text { GRZ, Zambia Sugar (was } \\
\text { state company when KASCO } \\
\text { started), DBZ, and other } \\
\text { investors }\end{array}$ & European Union & $\begin{array}{l}\text { African Development Bank, } \\
\text { Ministry of Foreign Affairs } \\
\text { Finland, GRZ }\end{array}$ \\
\hline
\end{tabular}

Sources: Struyf and Chuba (2009); Bangwe and van Koppen (2012); Swennenhuis (2015); SIP (2016). 
The most successful irrigation schemes in Zambia involve four main players, each with specific roles: (i) a processing firm; (ii) a nucleus estate or farmer company; (iii) an outgrower trust or association; (iv) outgrowers. In addition to these, there is need for a service provider, whose role may be at the stage of setting up the operation, or throughout.

The role of the mill is that of providing a market for output, and pumping water to reservoirs at the company or nucleus estate, as the water rights from the river are expected to be owned by the mill/processor (e.g. for the Kafue river, water rights for sugarcane production have been allocated to Zambia Sugar Plc and Consolidated Farming).

The nucleus estate or company, on the other hand, has to be owned by farmers. Its role is that of decision-making relating to production and output. It also markets produce on behalf of outgrowers, while providing inputs (e.g. pumping water to farmers' fields, supplying fertilizers and herbicides) and services within the irrigation scheme.

The role of an outgrowers' or farmers' association is that of resolving disputes, and representing farmers' interests. Where an independent service provider is engaged for cane haulage or planting activities, whether in the short run or medium term, this assists in production management early in the project, when farmers' capacity to manage their own fields is still being developed. Farmers/outgrowers, on the other hand, may manage their fields and crop production.

Except for KASCOL, participation in the irrigation schemes was based on residence in the project area, with projects targeting vulnerable communities initially displaced during the construction of the Kariba dam. For KASCOL, farmers were selected by government and traditional leaders, but there were no selection criteria, save for the fact that they had to successfully complete six months' training.

Across all schemes, sugar prices are based on an estimated sucrose recovery percentage determined at the mill's laboratory, with no negotiation around the sugar price, save for the monitoring of the analysis of sugar content by farmers' representatives.

\section{What are the differences across the irrigation schemes?}

There are notable differences in the organization of production across the three schemes, with likely implications on profit levels for outgrowers in particular. These include differences in land tenure arrangements, crops grown, restrictions on the use of irrigation water, management of field operations, and the provision of the initial inputs and funding.

For KASCOL, project funding was by donor agencies and the Development Bank of Zambia (DBZ), while, under the Magobbo scheme, project funding came from the European Union with a condition that beneficiaries also fund the project. Because beneficiaries could not contribute any funds, Zambia Sugar funded the difference, while deducting this from outgrower sugarcane sales. Under the Manyonyo irrigation scheme, project funding was provided by the donor agencies, and inputs were financed through commercial loans.

In terms of land ownership, the preferred form of finance has been that of a block title deed by the company, owned by the smallholders; the idea is that this increases their access to finance. Because smallholders contribute land to sugarcane production, their exit costs are assumed to be higher, thus enhancing their ties to the processor. With regard to the three models discussed 
here, KASCOL and Magobbo have land under leasehold tenure, with the title owned by their respective companies. While Manyonyo has land under private and customary tenure, it was still able to acquire commercial cash loans-indicating that a block title is not needed to acquire commercial loans for production. However, it is unclear what implications the individual titles may have on the exit of households or transfer of ownership over time.

In terms of production, KASCOL farmers are not allowed to grow any other crops on the sugarcane plots; instead, they can grow subsistence crops on an additional 0.5 ha of land. At Manyonyo and Magobbo, farmers have more land to use to produce other crops, and water for irrigation is not restricted to sugarcane only.

With respect to farmer participation in the models, there is low participation in both the Magobbo and Manyonyo schemes, with participation lowest for Magobbo. This is perhaps because of the initial conditions, whereby Zambia Sugar provided funding for inputs and engaged a service provider (a subsidiary) to produce on behalf of the farmers. Under KASCOL, ownership of the scheme is strong, as farmers carry out the production activities themselves. This may have important implications for not only profit levels, but also levels of trust and sustainability, even though all three schemes have so far proved sustainable.

\section{Weaknesses}

There are notable weaknesses to the nucleus estate model. While it is hailed as a success with respect to increasing the welfare status of participating farmers, female participation remains low, ranging from 6 per cent to 30 per cent across the three irrigation schemes. Furthermore, the high income levels among outgrowers, and the high traffic of seasonal and migratory labourers, triggers behaviour that increases outgrowers' risk of contracting HIV. ${ }^{1}$

Moreover, as is the case for outgrower schemes, there appears to be mistrust between farmers and sugarcane outgrowers regarding the price of sugarcane, which is computed as a percentage of recoverable sucrose, despite farmers having representation at the mill's laboratory when this is estimated.

\section{Implications for large-scale biofuel investments}

The outgrower schemes we have reviewed have been hailed as a success in their operations, and can be adopted or adapted for biofuel production. For large-scale biofuel feedstock production, initial conditions (i.e. the government's commitment to commercialize and diversify agricultural production, reduce poverty, and agricultural value addition and minimize rural-to-urban migration) favour production in farm blocks, which have driven success in existing sugarcane irrigation schemes. The case for feedstock production is also strengthened by the fact that this will likely yield the least negative outcomes under current conditions and will yield more positive spillovers than industrial investments in sugar (Hichaambwa and Matenga 2016; Samboko et al. forthcoming b).

There is likely to be a big difference in land ownership between the three schemes discussed and that in the farm blocks. Since ownership in the farm blocks is largely expected to be private, and mostly acquired by an elitist population, it is vital that measures are put in place to allow wide participation by local farmers-particularly as this may have implications for inequality and

\footnotetext{
${ }^{1}$ There is generally a poor strategy around HIV/AIDS, even though farmers have recently been paid on a monthly basis instead of annually to help address this problem (Struyf and Chuba 2009).
} 
future income growth. A block title in this case would be preferable, as it would limit the holding of land for speculative reasons by the urban-based elite.

In terms of the role of various players, feedstock production under this model is in sync with the government's vision of farm block development, whereby farms in the range 1,001-10,000 ha provide market and grower services to those owning between 5 and 1,000 ha. On paper, each farm block is designed to have farms in each of five categories: Category 1 (5-10 ha); Category 2 (11-100 ha); Category 3 (101-1,000 ha); Category 4 (1,001-5,000 ha); and Category 5 (5,001$10,000 \mathrm{ha})$.

The role played by the contract growers and their families would be that of managing their fields (i.e. irrigation within fields, weeding, fertilizer application, and other production-related activities). To reduce transaction costs, the outgrowers would have to be organized in farmer groups, and an association would have to be set up to represent their interest to the nucleus estate. However, it is crucial that early stage management of field crops is done by specialized units to enable farmers to acquire the management expertise.

Further, large-scale biofuel projects will also have to take into account other unintended social outcomes in the project designs-especially increased HIV infection. Without careful consideration of the threat this poses to the viability of the industry, and the continuous participation of outgrowers in the scheme, access to funding may be difficult, or the project may face problems in future.

\subsection{Small-scale feedstock production models for biofuels}

In the previous section, we discussed a model suitable for the large-scale production of biofuel feedstocks to serve both local and international markets. In this section, we consider the models best suited to small- to medium-scale biofuel production mainly for the local market, and mainly for biodiesel feedstocks, save for cassava ${ }^{2}$ in the case of bioethanol. This is important, as smallerscale feedstock production may be more efficient, with implications for international competitiveness, as observed for cotton in Zambia (see World Bank 2009).

These models are likely to be those that involve many smallholders country-wide, and we argue that, through them, benefits to the 1.5 million or more small-scale farmers will be more widespread, given the backward and forward linkages created by the biofuels industry.

From the literature, Dunavant's (now NWK Agri Services) distributor model appears to be a candidate for successful feedstock production. Its organization is such that it deals with sideselling - a major problem in outgrower schemes involving many contracting parties (presently 11 for cotton in Zambia) (Kabwe 2016). More recent results on cotton side-selling show that only 17 per cent of households engage in this practice-mostly male-headed households. This is largely driven by delayed payments or purchase of cotton, which increase the propensity to sidesell given the pressing need among farmers to settle school fees, purchase food and clothes, and pay for healthcare. Farmers are thus more likely to sell to ginners that pay on the spot as opposed to those that delay payment for several days. This reduces transaction costs to the firm.

The basic idea behind the distributor model is to have a network of localized distributors (usually large farmers), who have smaller farmers under them. Distributors select outgrowers, and are

\footnotetext{
${ }^{2}$ Almost all the cassava produced in Zambia is grown by smallholder farmers, making production under smallholder outgrower schemes suitable.
} 
responsible for extension service provision, input provision, negotiations with the firm, the organization of input and product deliveries, and loan recoveries from the farmers under them. To access loans, the distributor provides collateral to the contracting firm. Depending on their performance in ensuring product quality, loan recovery, and quantity of product supplied, distributors are paid a commission (World Bank 2009).

However, the model cannot operate successfully without support from other institutions, such as The Cotton Board of Zambia (CBZ), the Cotton Ginners Association (CGA), and the Cotton Association of Zambia (CAZ). CBZ was set up following the cotton sector's first crash in 1999/2000. Its functions are limited to issuing licences to cotton ginners, sellers, and producers, and maintaining records of cotton producers (GRZ 2005).

The legislative framework governing the cotton industry is the cotton Act of 2005, which details punitive measures for unacceptable conduct in the industry) (Kabwe 2012). The Act also provides for the CBZ, through inspectors, to regulate and enforce input supply contracts (Tschirley and Kabwe 2010). Essentially, this has reduced the presence of unscrupulous businessmen and independent traders, who have interfered with the marketing of cotton in the past, and also minimized side-selling.

Usually, ginners hold monthly meetings, organized by the District Agricultural Coordinator, who is a government employee, and the cotton inspector. The industry is governed by a code of conduct, and usually, a memorandum of understanding is signed among ginners to help curb side-selling (Kabwe 2016).

However, there is no cotton pricing mechanism in place. Attempts by the CGA and CAZ have met with strong resistance from the Competition and Consumer Protection Commission, which has accused the two of colluding (Tschirley and Kabwe 2010). This means that mistrust in pricesetting is still a problem in the industry.

\section{Implications for smallholder-led biofuel investments}

If outgrower production models are to be adopted in smallholder-led biofuel projects (mainly for biodiesel feedstock production), the analysis above suggests that the distributor model is more appealing, as it has the least transaction costs and enhances contract enforcement. However, as is shown by the issues that may arise from inadequate regulation for cotton in Zambia, there is a need for:

- A comprehensive biofuels regulatory framework that ensures acceptable behaviour among industry players

- A proper price-setting mechanism to minimize mistrust between feedstock outgrowers and firms. This should also ensure equity in the distribution of proceeds. If biofuels will be traded on international markets, hedging against exchange rate volatility will be key to avoiding wrangles with smallholders.

- Provision of public goods such as roads and irrigation facilities

- Improvements in institutions such as land tenure.

\section{Concluding remarks}

This study has sought to identify appropriate institutional arrangements for biofuel feedstock production in Zambia, with a priori information that the likely feedstocks are sugarcane, sweet 
sorghum, and cassava, for bioethanol, and soybean, sunflower, and groundnuts for biodiesel. We argue that large-scale production of biofuels will have to be organized with four main parties to the model, namely: (i) a biofuel processing firm; (ii) a nucleus estate/company; (iii) an outgrower trust or association; and (iv) outgrowers or smallholders. We add a service provider as a fifth party responsible for the management of production, particularly in the early stages; this must be independent from the off-taker of biofuel feedstocks for transparency and to avoid the possibility of hidden costs if it is owned or managed by the processor. Given the importance of spillovers from such an investment, farm blocks have the advantage of offering an opportunity to generate more spillovers than an industrialized set-up such as that for sugarcane. Any negative social outcomes that may come with a biofuels expansion programme need to be anticipated and planned for in the project design.

For smallholder-led biofuel production for biodiesel, as well as for bioethanol (using cassava), production should be organized using the distributor model, as this has been shown to be highly successful in dealing with contract enforcement and transaction costs. However, it should be supported by a strong regulatory framework that sanctions any behaviour deviating from an accepted code of conduct.

\section{References}

Bangwe, L., and B. van Koppen (2012). Smallholder Outgrowers in Irrigated Agriculture in Zambia. AgWater Solutions Project. Available at: http://awmsolutions.iwmi.org/Data/Sites/3/Documents/PDF/Country_Docs/Zambia/zambiaoutgrowers.pdf (accessed August 2016).

CSBF (Civil Society Biofuels Forum) (2009). 'Report on the Analysis of the Policies and Regulatory Arrangements of the Liquid Biofuel Industry in Zambia'. Lusaka: Civil Society Biofuels Forum.

Gasparatos, A., L.Y. Lee, G. von Maltitz, M.V. Mathai, J.A.P. de Oliveira, and K.J. Willis (2012). 'Biofuels in Africa: Impacts on Ecosystem Services, Biodiversity and Human Wellbeing'. Policy Report. Yokohama: UNU-IAS. Available at: http://www.ias.unu.edu/resource_centre/Biofuels_in_Africa.pdf (accessed March 2017).

German, L., G.C. Schoneveld, and D. Gumbo (2011). 'The Local Social and Environmental Impacts of Smallholder-based Biofuel Investments in Zambia'. Ecology and Society, 16(4): 12.

GRZ (Government of the Republic of Zambia) (2005). 'Cotton Act 21 of 2005'. Available at: http://www.parliament.gov.zm (accessed March 2017).

Hichaambwa, M., and C. Matenga (2016). Which Large-scale Agricultural Commercialisation Models Offer the Best Opportunities for Improved Local Livelihoods in Zambia? Lusaka: Indaba Agricultural Policy Research Institute (IAPRI). Available at: http://fsg.afre.msu.edu/zambia/ps80.pdf (accessed October 2016).

Kabwe, S. (2012). 'Revisions to the Cotton Act of 2005'. Paper presented at the Cotton Ginners Association Meeting. Chipata: IAPRI. Available at: http:// fsg.afre.msu.edu/zambia/Revisions_Cotton_Act_2005_ZCGA_wayforwardV1.pdf (accessed November 2016).

Kabwe, S. (2016). 'Assessing the Level of Side Marketing in Seed Cotton and the Factors Associated with it in Zambia'. Chipata: IAPRI. Available at: http://www.iapri.org.zm/images/Presentations/Informality_in_Cotton_Zambia.pdf (accessed November 2016). 
Loos, T.K. (2009). Socioeconomic Impact of Jatropha Project on Smallholder Farmers in Mpanda, Tanzania. University of Hohenheim. Institute for Agricultural Economics and Social Sciences in the Tropics and Subtropics. Available at: https://troz.unihohenheim.de/fileadmin/einrichtungen/troz/Documents/Bioenergy/M.Sc.Loos_Tansania .pdf (accessed November 2016)

Mungandi, S., D. Conforte, and N.M. Shadbolt (2012). 'Integration of Smallholders in Modern Agri-food Chains: Lessons from the KASCOL Model in Zambia'. International Food and Agribusiness Management Review, 15(3). Available at: http://ageconsearch.umn.edu/bitstream/133495/2/20110041.pdf (accessed October 2016).

Samboko, P.C., M. Subakanya, and C. Dlamini (forthcoming a). 'Potential Biofuel Feedstocks and Production in Zambia'. UNU-WIDER Working Paper.

Samboko, P., M. Kabisa, C. Dlamini, and G. Henley (forthcoming b). 'Constraints to Biofuel Feedstock Production in Zambia'. UNU-WIDER Working Paper.

Sartorious, K., J.F. Kirsten, and M. Masuku (2003). A New Institutional Economic Analysis of Small Farmer Contracts and Relations in the Sugar Supply Chains in South Africa and Swariland. Available at:

https://www.researchgate.net/publication/2841518_A_new_institutional_economic_analys is_of_small_farmer_contracts_and_relations_in_the_sugar_supply_chains_in_South_Africa _and_Swaziland (accessed 8 August 2016).

Schoneveld, G.C., L.A. German, and E. Nutakor (2011). 'Land-based Investments for Rural Development? A Grounded Analysis of the Local Impacts of Biofuel Feedstock Plantations in Ghana'. Ecology and Society, 16(4): 10. Available at: http://www.ecologyandsociety.org/vol16/iss4/art10/ (accessed April 2016).

Shumba, E., P. Roberntz, and M. Kuona (2011). Assessment of Sugarcane Outgrower Schemes for Biofuel Production in Zambia and Zimbabwe. World Wide Fund For Nature. Available at: http://d2ouvy59p0dg6k.cloudfront.net/downloads/assessment_of_sugarcane_outgrower_s chemes_for_bio_fuel_production_3.pdf (accessed July 2016).

SIP (Small-scale Irrigation Project) (2016). The Organization of Irrigation Schemes in Zambia. Interview by P.C. Samboko, September.

Struyf, G., and N. Chuba (2009). Study to Examine the Feasibility of the Expansion of Sugar Outgrowers Schemes in Zambia. GRM International.

Swennenhuis, J. (2015). Evaluation of the Small-scale Irrigation Project (Zambia). Lusaka: Ministry of Agriculture.

Tschirley, D., and S. Kabwe (2010). 'A Case Study of Regulation in Zambia's Cotton Sector’. Food Security Research Project Working Paper 45. Lusaka: Food Security Research Project.

World Bank (2007). Zambia Smallholder Agriculture Commercialization Strategy. Washington, DC: World Bank. Available at: http://documents.worldbank.org/curated/en/149311468169778223/pdf/365730ZM.pdf (accessed October 2016).

World Bank (2009). Awakening Africa's Sleeping Giant: Prospects for Commercial Agriculture in the Guinea Savannah Zone and Beyond. World Bank. Available at: http://siteresources.worldbank.org/INTARD/Resources/sleeping_giant.pdf (accessed October 2016). 